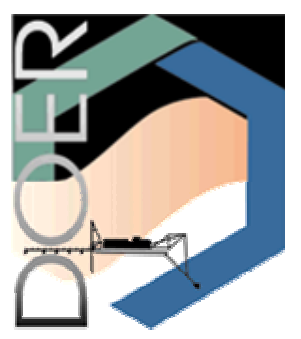

ERDC TN-DOER-R4

September 2004

\title{
Development of Gene Expression Fingerprints for Identification of Environmental Contaminants Using cDNA Arrays
}

PURPOSE: This technical note reports the current status of work being done at the U.S. Army Engineer Research and Development Center (ERDC) to develop cDNA array-based assays that map gene expression from contaminant exposures. Results substantiate that distinct gene expression profiles exist for major contaminant classes such as PAHs, PCBs, and PCDD/Fs. Results also indicate that identification of these contaminant mixtures in environmental media is possible by examining their effects on gene expression in mammalian cells.

BACKGROUND: Research at ERDC directed at developing screening assays for contaminated sediments has been applied to extracts of both sediments and the organisms living in them. Several microbial and cell-based in vitro methods are now routinely used for this purpose. These were described, and the possibilities of using cDNA arrays in a screening assay were explored, in a preceding Technical Note (TN-DOER-C19, Inouye and McFarland (2001)). Briefly, cDNA arrays allow quantification of gene expression profiles (genes that are "turned on or off" at a selected time) providing a "fingerprint" of the sub-cellular responses of the test subject, e.g., cultured human liver cells, to a chemical challenge. While current in vitro tests such as the $101 \mathrm{~L}$ cell-based assay for dioxin equivalents (TN-DOER-C10, Ang et al. (2000)) offer inexpensive and rapid screening of one endpoint, cDNA arrays offer the potential for simultaneous screening of multiple endpoints and mixtures of contaminants. The activation of multiple genes related to disruption of normal cell functions, such as apoptosis, tumor suppression, cell proliferation, cell cycles, cytokines, oxidative stress, and more, can be measured in a single exposure using cDNA arrays. The resulting information can provide valuable insights into the toxic modes of action (MOAs) of mixtures of contaminants present in sediments. This is not possible with chemical analysis or any other current methods. Mode-of-action information can be used in several ways: the need for, and the type of, more time-consuming and expensive chronic sublethal bioassays (e.g., survival, growth, reproduction, genotoxicity) as well as costly and expensive chemical analysis can be identified -- or their necessity can be eliminated. A priori interpretations of the presence of known chemicals in sediment/soil samples are more defendable if accompanied by mechanistic information, i.e., MOA, and the decisions that result are more certain.

In this investigation a cultured cell line (human hepatoma, HepG2) was exposed to known compounds/mixtures in order to develop genetic-response fingerprints for common contaminant classes; future work will involve testing extracts of environmental samples (sediments, tissues) to relate the responses seen with model chemicals to those of complex mixtures present in field samples. Gene responses were monitored with Clontech's commercially available Atlas ${ }^{\mathrm{TM}}$ Human Toxicology 1.2 cDNA array, which includes 1176 genes known to be involved in toxicological responses, e.g., genes linked to DNA synthesis/repair, stress proteins, and tumor suppression or induction. Results substantiate that distinct gene expression profiles exist for 
major contaminant classes such as PAHs, PCBs, and 2,3,7,8 -tetrachlorodibenzo[ $p$ ]dioxin $(2,3,7,8$ TCDD).

\section{METHODS AND MATERIALS:}

Cell Exposures and cDNA Array Assay. HepG2 cells were exposed to the model chemical contaminants, and the cellular mRNA was harvested. For each exposure, four replicate T-150 culture flasks were seeded with $5 \times 10^{6} \mathrm{HepG} 2$ cells, allowed to grow to 80-percent confluency, and then dosed. Table 1 lists nominal dose levels and concentrations of the individual chemicals in the mixtures. Contaminants were added in $150-\mathrm{uL}$ aliquots of isooctane to the $15-\mathrm{mL}$ minimum essential medium (MEM) media in each flask; a solvent control (150 uL of iso-octane) was dosed at the same time. Cells were exposed for $16 \mathrm{hr}$ to either pure 2,3,7,8tetrachlorodibenzo[ $p]$ dioxin (TCDD, Ultra Scientific \#RPE-029S), a PAH mixture (Ultra Scientific \#PM-810), or a PCB mixture (Aroclor 1254, EPA-Research Triangle Park \#5705), each at three dose levels. All dose levels for all compounds in this investigation were below acutely toxic doses, as monitored by trypan blue viability stain. Cells were exposed to the test chemicals for $16 \mathrm{hr}$, washed with 1x phosphate buffered saline (PBS), counted, and centrifuged. The cell pellets were stored in 5 volumes of RNAlater (Ambion \#7021) at $-20^{\circ} \mathrm{C}$ for RNA isolation. The mRNA was isolated using Clontech's Atlas ${ }^{\text {TM }}$ Pure Total RNA Labeling Kit with modifications; details of the RNA isolation procedure are provided in Appendix A.

Following isolation, the mRNA was converted into cDNA (Figure 1) using reverse transcription. Procedures for Clontech's SpotLight ${ }^{\mathrm{TM}}$ Random Primer Labeling Kit were followed (http://www. bdbiosciences.com/clontech/techinfo/manuals/PDF/PT3516-1.pdf). The only modification was the use of the CDP-Star primers provided with the arrays. Briefly, the extracted mRNA was placed in a tube with "primers," or short DNA sequences (oligonucleotides), which bind to complementary sequences on the mRNA targets; primers are optimized for the genes targeted on the array, and used as provided by the manufacturer with the arrays. An enzyme then binds to the primer/mRNA complex and makes a complementary DNA copy of the mRNA sequence (cDNA). The cDNA is also labeled during this step with biotin, which allows chemiluminescent visualization after it is bound to the array.

The resulting cDNA was bound (hybridized) to the array in a complementary sequence-specific manner during overnight exposure. Gene responses were quantified by the amount of biotinlabeled cDNA bound at each spot on the array as detected via a light-producing reaction in which Streptavidin-bound horseradish peroxidase binds specifically to the biotin label incorporated in the cDNA. Methodologies for the Clontech Spotlight ${ }^{\mathrm{TM}}$ Chemiluminescent Hybridization and Detection Kit were followed without modification for both hybridization and detection. The light output was captured using a digital imaging analysis system (AlphaInnotech's Fluorchem 8000). Representative results from control and exposed arrays are shown in Figure 2.

Data analysis. The digital images of the arrays were analyzed with AtlasImage 2.0 (Clontech), which provides local background and spot densitometry data for all genes. Background corrected data were summed for all genes in the array, and the data were then normalized to the total intensity of all spots to allow comparisons between arrays, since the amount of cDNA applied to each array may differ. 


\begin{tabular}{|c|c|c|c|}
\hline \multicolumn{4}{|c|}{$\begin{array}{l}\text { Table } 1 \\
\text { Contaminant Dosing for HepG2 Cells (Nominal Concentrations) }\end{array}$} \\
\hline PM180 Mixture Component list & High PAH (ug/L) & Mid PAH (ug/L) & Low PAH (ug/L) \\
\hline acenaphthene & 251 & 25.1 & 2.5 \\
\hline acenaphthylene & 251 & 25.1 & 2.5 \\
\hline anthracene & 251 & 25.1 & 2.5 \\
\hline benz[a]anthracene & 25 & 2.5 & 0.3 \\
\hline Benzo[b]fluoranthene & 25 & 2.5 & 0.3 \\
\hline Benzo[k]fluoranthene & 13 & 1.3 & 0.1 \\
\hline Benzo[ghi]perylene & 25 & 2.5 & 0.3 \\
\hline Benzo[a]pyrene & 25 & 2.5 & 0.3 \\
\hline chrysene & 25 & 2.5 & 0.3 \\
\hline dibenz[a,h]anthracene & 25 & 2.5 & 0.3 \\
\hline fluoranthene & 25 & 2.5 & 0.3 \\
\hline fluorene & 251 & 25.1 & 2.5 \\
\hline indeno[1,2,3-cd]pyrene & 25 & 2.5 & 0.3 \\
\hline naphthalene & 251 & 25.1 & 2.5 \\
\hline phenanthrene & 251 & 25.1 & 2.5 \\
\hline pyrene & 25 & 2.5 & 0.3 \\
\hline SUM PAH & $1740 \mathrm{ug} / \mathrm{L}$ & $174.0 \mathrm{ug} / \mathrm{L}$ & $17.4 \mathrm{ug} / \mathrm{L}$ \\
\hline Aroclor $1254^{1}\left(\mathrm{C}_{12} \mathrm{H}_{(10-\mathrm{x})} \mathrm{Cl}_{\mathrm{x}}\right)$ & High Aroclor (ug/L) & Mid Aroclor (ug/L) & Low Aroclor (ug/L) \\
\hline$x=2$ & 0.24 & 0.024 & 0.0024 \\
\hline$x=3$ & 1.26 & 0.126 & 0.0126 \\
\hline$x=4$ & 10.25 & 1.025 & 0.1025 \\
\hline$x=5$ & 59.12 & 5.912 & 0.5912 \\
\hline$x=6$ & 26.76 & 2.676 & 0.2676 \\
\hline$x=7$ & 2.66 & 0.266 & 0.0266 \\
\hline$x=8$ & 0.04 & 0.004 & 0.0004 \\
\hline$x=9$ & 0.04 & 0.004 & 0.0004 \\
\hline \multirow[t]{2}{*}{ SUM PCBs } & $100 \mathrm{ug} / \mathrm{L}$ & $10 \mathrm{ug} / \mathrm{L}$ & $1 \mathrm{ug} / \mathrm{L}$ \\
\hline & High TCDD & Mid TCDD & Low TCDD \\
\hline 2,3,7,8-TCDD & 100 ng/L (311 pM) & 25 ng/L (78 pM) & $7.5 \mathrm{ng} / \mathrm{L}(23 \mathrm{pM})$ \\
\hline
\end{tabular}

The data were then analyzed using a semi-parametric technique that uses local regression to estimate the normalized expression levels as well as the expression level-dependent error variance (Kepler et al. 2002). The technique is based on assumptions that the large majority of genes will not have their relative expression levels changed from one treatment group to the next, and that departures of the response from linearity are small and vary slowly. For each compound, gene responses at each dose were compared to controls independently. The statistical data and gene expression data were then examined to determine which genes were responding consistently across all doses. 
ERDC TN-DOER-R4

September 2004

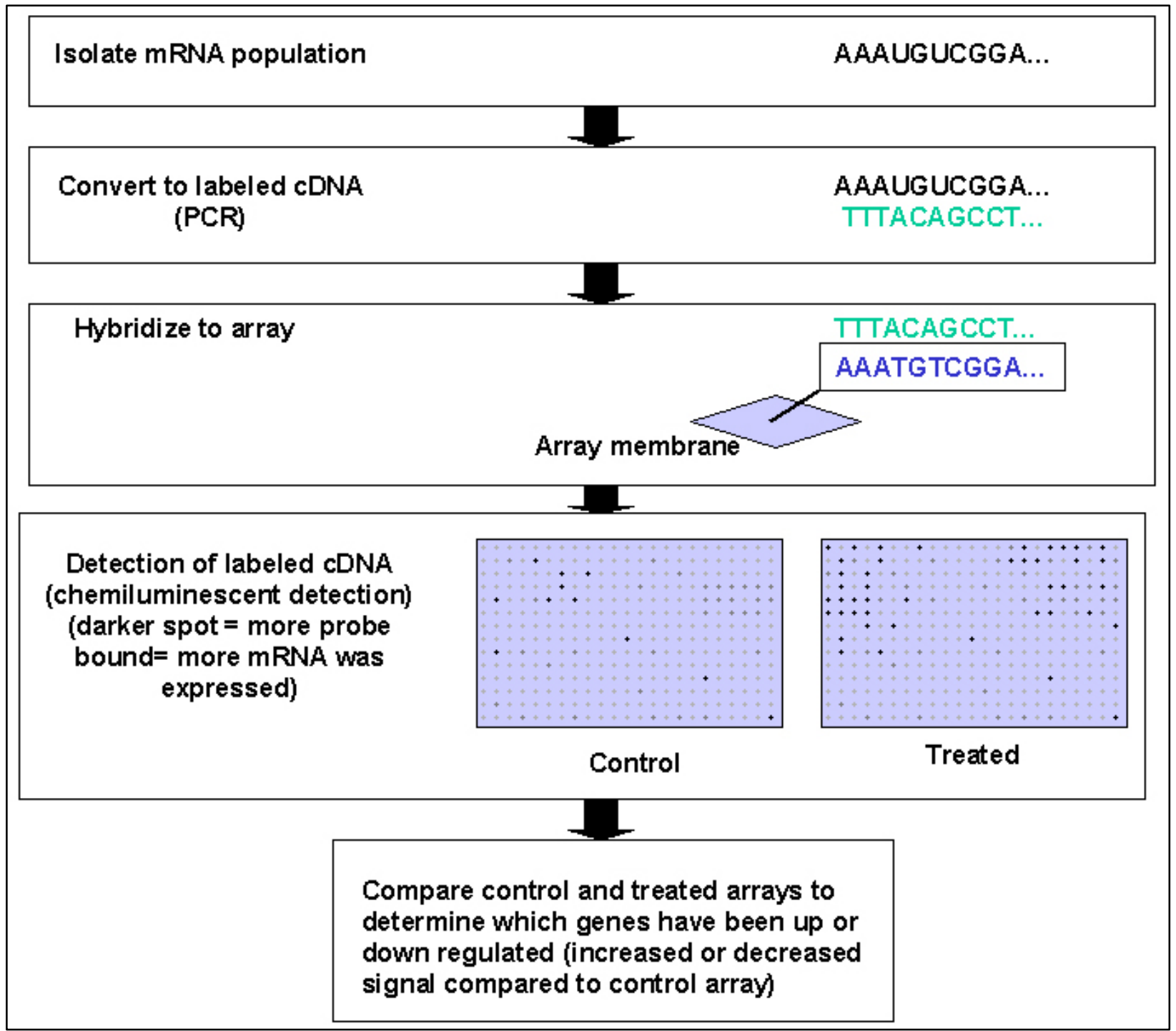

Figure 1. An overview of the cDNA array assay. The mRNA populations are isolated from control and treated cell cultures (a partial sequence shown to the right as an example), converted to tagged cDNA (shown in green), and hybridized to the cDNA bound to the array (one of the genes on the array shown in blue) 

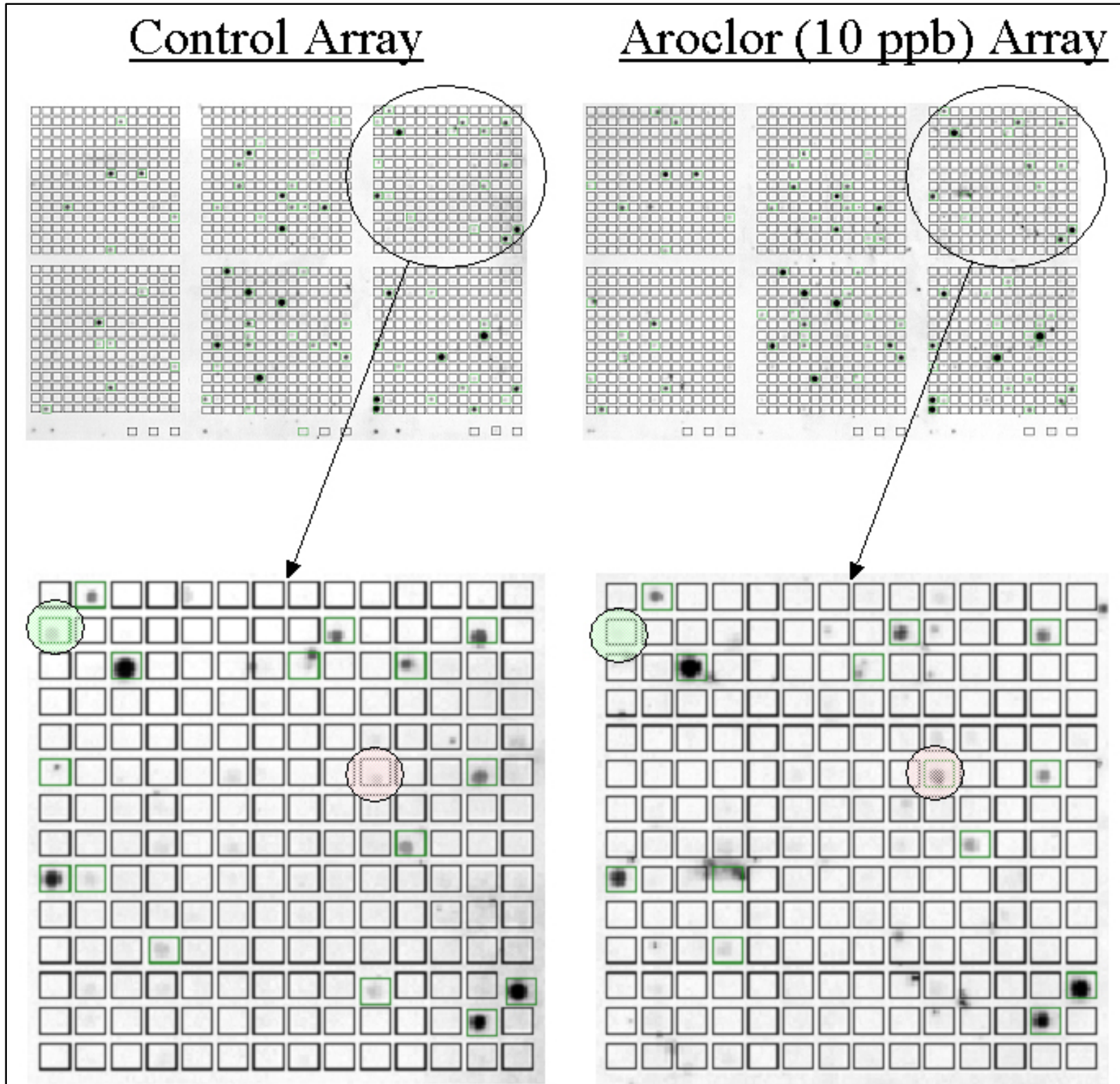

Figure 2. Example arrays. Photos at the top of the figure are from the Aroclor (PCB mixture) exposure; only the control and 10-ppb dose are shown. One sector is enlarged to show details, with examples of up regulation (increase in gene expression, highlighted in red circle) and down regulation (decrease in gene expression, highlighted in green circle)

RESULTS AND DISCUSSION: Gene responses are dependent on the exposure time, exposure dose, and contaminant being investigated. Choice of the 16-hr time point for observations in this study was operationally based. Logistically, post-exposure washing and counting procedures make it difficult to time exposures with a precision better than $+/-30$ minutes. Additionally, investigations of the time course of gene expression in HepG2 cells have shown that many genes are approaching maximal induction by 8 to $18 \mathrm{hr}$, as monitored by real-time PCR (RT-PCR) (Frueh et al. 2001). 


\section{ERDC TN-DOER-R4}

\section{September 2004}

In the current results, any given dose for any given compound resulted in differential expression (altered expression as compared to that of the solvent control) in approximately 3-6 percent of all the genes on the array. This result is consistent with observations of other groups who have conducted gene expression experiments with HepG2 cells using various compounds. For example, Ishida et al. (2002) found 0.2 to 0.8 percent of genes responded to exposures below toxic concentrations on the Affymetrix gene chip containing 12,626 oligomers. Compounds tested included model inducers such as $\alpha$ - and $\beta$-naphthoflavone and omeprazole. Most other studies have been conducted at toxic doses, which resulted in more genes being differentially expressed. In experiments conducted with Clontech Human Toxicology II arrays containing 588 genes, concentrations of chemicals causing 20 to 30 percent cell death resulted in significant alterations in gene expression for 4 percent (carbon tetrachloride) and 15 percent (ethanol) of the monitored genes (Harries et al. 2001). In another study, etomoxir, a mitochondrial enzyme inhibitor, elicited significant alterations of 9.4 percent of the genes on the Clontech Human Stress Toxicology array containing 234 genes (Merrill et al. 2002). Detailed analysis of individual gene expression alterations and how they change with increasing dose can provide insight into the mechanisms of toxicity of specific compounds. However, to apply this technology to environmental monitoring, it is only necessary that compounds possess unique gene expression profiles that are sustained over a large dose range.

In order to determine whether gene responses were characteristic for the different compounds, all genes that were expressed at a significantly different level than their corresponding control were combined for a given compound regardless of dose, and the resultant list of genes compared between the compounds. The Vin diagram in Figure 3 displays the overlap in responding genes between the treatments; the box in each circle defines the compound the circle represents, with the total number of responding genes in parentheses; overlapping sectors represent genes in common for the compounds, with the number enclosed in the overlapping sectors representing the number of genes in common. Some overlap in differentially expressed genes was observed, which was expected since selected PCBs and PAHs are known to interact with the same receptor system responsible for toxicity of TCDD. However, the bulk of the genes were unique to each treatment, with only two genes responding to all three treatments; only 32 of the combined 320 genes were differentially expressed by more than one compound, supporting the application of this technique for identifying contaminants and/or contaminant classes. However, for application as a screening technique for environmental samples it is also desirable that the genes respond in a consistent manner across a wide range of doses. This requirement reduces the number of selected genes, as some genes that respond at lower doses may not respond at higher doses, and vice versa. The wide dose range over which the response was required to be consistent explains the lack of expected response of some genes, such as cyp1A1 for TCDD. Frueh et al. (2001) used RT-PCR to determine the concentration-dependent gene response to 2,3,7,8-TCDD in HepG2 cells, and found that many of the genes are not induced until concentrations reach at least 100 pM TCDD; the doses in this study were equivalent to 311,78 , and 23 pM TCDD. The gene was thus eliminated, as the selection criteria depended on a consistent response over the entire dose range, and cyp1A1 was only induced in two of the three tested doses. 


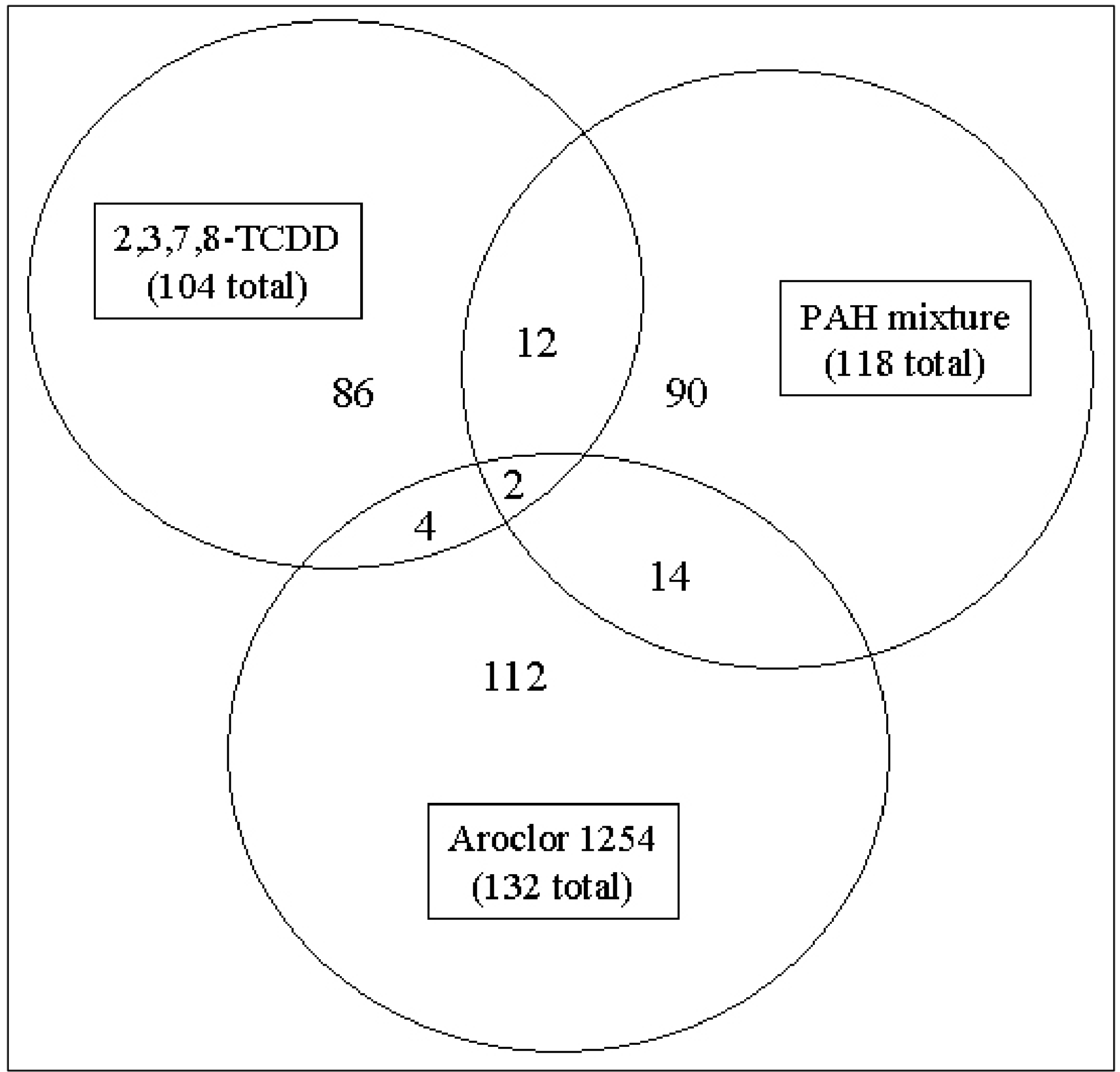

Figure 3. Vin diagram indicating the numbers and overlaps for significant gene responses; all genes responding at any dose of a particular treatment were combined

Most gene array studies have been conducted at only one dose. One exception is Bartosiewicz et al. (2001), who conducted their exposures in mice and monitored gene expression in the livers using a 148-gene array. The design included cadmium chloride $\left(\mathrm{CdCl}_{2}\right)$ at five doses ranging from 0.1 to $10 \mathrm{mg} / \mathrm{kg}$, benzo-[a]-pyrene (B[a]P) at four doses ranging from 0.1 to $100 \mathrm{mg} / \mathrm{kg}$, and tetrachloroethylene (TCE) at three doses ranging from 10 to $1000 \mathrm{mg} / \mathrm{kg}$. These doses cover two to three orders of magnitude in concentrations; similarly, the current study covered two orders of magnitude for the PAH mixture and PCB mixture, and less than two orders for TCDD. Although many genes responded to the toxicants in the Bartosiewicz et al. study $(13,2$, and 3 genes for $\mathrm{CdCl}_{2}, \mathrm{~B}[\mathrm{a}] \mathrm{P}$, and TCE respectively), none of them responded over the entire range tested. The number of genes that responded over a tenfold dose range drops to 2, 2, and 0 for 
$\mathrm{CdCl}_{2}, \mathrm{~B}[\mathrm{a}] \mathrm{P}$, and TCE, respectively. Results showed a similar decrease in the numbers of genes that responded in a consistent manner across all doses, with 18 consistent genes for TCDD, 2 for PCBs, and 14 for PAHs. There was no overlap between the consistently responding genes for the three compounds/mixtures tested; gene ID, dose-related responses, and statistical data can be found in Appendix B. The existence of these unique genes whose expression is consistently affected by exposure to contaminants provides support for the hypothesis that gene expression can be used to detect and identify chemical classes of contaminants by their MOAs as evidenced by gene expression in environmental samples.

CONCLUSIONS AND FUTURE DIRECTIONS: Gene expression profiles for the tested contaminants and contaminant mixtures appear to be characteristic of the test compounds and consistent over a large dose range, and thus may be useful for toxicant identification in field samples. However, confirmation of the gene responses via a secondary methodology such as RTPCR is necessary. Additionally, in order to make this approach useful in simultaneously detecting multiple contaminants in environmental samples, testing chemical mixtures with mixed MOAs (e.g. combined exposure to PAHs and TCDD) is needed to determine whether the fingerprints are additive, and whether interactions between the contaminant classes alter the contaminant-specific responses observed and reported herein.

The number of potentially unique, dose-responsive genes is small enough to allow for the generation of a smaller customized array, or development of more rapid/less expensive methods for quantifying them (RT-PCR, glass arrays, etc.). If the expression fingerprints remain intact in exposures to the more complex mixtures found in environmental samples, it may be possible to rapidly assess the presence of multiple contaminants in a single assay (presence of unique expression fingerprint), as well as to assess the severity of the contamination (intensity of alterations in gene expression).

POINTS OF CONTACT: For additional information, contact one of the authors, Dr. Laura S. Inouye, (601) 634-2910, Laura.S.Inouye@erdc.usace.army.mil; or Dr. Victor A. McFarland, (601) 634-3721, Victor.A.McFarland@erdc.usace.army.mil, or the Manager of the Dredging Operations and Environmental Research Program, Dr. Robert M. Engler, (601) 634-3624, Robert.M.Engler@erdc.usace.army.mil.

This technical note should be cited as follows:

Inouye, L. S., Ang, C. Y., and McFarland, V. A. (2004). "Development of gene expression fingerprints for identification of environmental contaminants using DCNA arrays," DOER Technical Notes Collection (ERDC TN-DOER-R4), U.S. Army Engineer Research and Development Center, Vicksburg, MS. www.wes.army.mil/el/dots/doer.

\section{REFERENCES}

Ang, C. Y., Inouye, L. S., McCant, D. D., and McFarland, V. A. (2000). "Protocols for a rapid clean-up/extraction procedure and an improved P450RGS dioxin screening assay for sediments," DOER Technical Notes Collection (ERDC TN-DOER C10), U.S. Army Engineer Research and Development Center, Vicksburg, MS. www.wes.army.mil/el/dots/doer. 
Bartosiewicz, M., Penn, S., and Buckpitt, A. (2001). "Applications of gene arrays in environmental toxicology: fingerprints of gene regulation associated with cadmium chloride, benzo(a)pyrene, and trichloroethylene," Environmental Health Perspectives 109(4), 71-74.

Frueh, F. W., Hayashibara, K. C., Brown, P. O., and Whitlock, J. P., Jr. (2001). "Use of cDNA microarrays to analyze dioxin-induced changes in human liver gene expression," Toxicology Letters 6;122(3), 189-203.

Harries, H. M., Fletcher, S, T., Duggan, C. M., Baker, V. A. (2001). "The use of genomics technology to investigate gene expression changes in cultured human liver cells," Toxicology In Vitro 15(4-5), 399-405.

Inouye, L. S. and McFarland, V.A., (2001) "Biomarker-based analysis for contaminants in sediments/soil: Review of cell-based assays and cDNA arrays," DOER Technical Notes Collection (ERDC TN-DOER C19), U.S. Army Engineer Waterways Experiment Station, Vicksburg, MS. www.wes.army.mil/el/dots/doer.

Ishida, S., Jinno, H., Tanaka-Kagawa, T., Ando, M., Ohno, Y., Ozawa, S., and Sawada, J. (2002). "Characterization of human CYP1A1/1A2 induction by DNA microarray and alphanaphthoflavone,” Biochemical-Biophysical Research Communications 296(1), 172-177.

Kepler, T. B., Crosby, L., Morgan, K. T. (2002). "Normalization and analysis of DNA microarray data by self-consistency and local regression," Genome Biology 28;3(7), research0037.1-12 (ftp://ftp.santafe.edu/pub/kepler/).

Merrill, C. L., Ni, H., Yoon, L.W., Tirmenstein, M. A., Narayanan, P., Benavides, G. R., Easton M. J., Creech, D. R., Hu, C. X., McFarland, D. C., Hahn, L. M., Thomas, H. C., and Morgan, K. T. (2002). "Etomoxir-induced oxidative stress in HepG2 cells detected by differential gene expression is confirmed biochemically," Toxicology Science 68(1), 93-101. 


\section{APPENDIX A}

CELL EXPOSURES: Human hepatoma HepG2 cells were counted and checked for viability with Trypan Blue dye using a hemacytometer and microscope. Cells with $>95$ percent viability or better were then seeded at $\sim 5 \times 10^{6}$ per T-150 flask $\left(150 \mathrm{~cm}^{2}\right.$ growing surface area) and allowed to grow for several days until the cells reached $\sim 80$ percent confluency. Replicate flasks were then dosed with isooctane (solvent control) at 1 percent $\mathrm{v} / \mathrm{v}$ or with the following compounds at different concentrations as shown in the table below.

\begin{tabular}{|c|c|c|}
\hline \multicolumn{3}{|c|}{$\begin{array}{l}\text { Table } 1 \\
\text { Media Concentrations of 2,3,7,8-tetrachlorodibenzo-p-dioxin, TCDD (Ultra Scientific \#RPE- } \\
\text { 029S), Polyaromatic Hydrocarbon Mix, PAH Mix (Ultra Scientific \#PM-810), and Aroclor } 1254 \\
\text { (EPA-Research Triangle Park \#5705) }\end{array}$} \\
\hline $2,3,7,8-T C D D$ & PAH Mix & Aroclor 1254 \\
\hline Isooctane & Isooctane & Isooctane \\
\hline $7.5 \mathrm{pg} / \mathrm{mL}$ & $1.7 \mathrm{ng} / \mathrm{mL}$ & $1 \mathrm{ng} / \mathrm{mL}$ \\
\hline $25 \mathrm{pg} / \mathrm{mL}$ & $17 \mathrm{ng} / \mathrm{mL}$ & $10 \mathrm{ng} / \mathrm{mL}$ \\
\hline $100 \mathrm{pg} / \mathrm{mL}$ & $170 \mathrm{ng} / \mathrm{mL}$ & $100 \mathrm{ng} / \mathrm{mL}$ \\
\hline
\end{tabular}

After $16 \mathrm{hr}$ of exposure to the compounds of interest, cells from the same treatment were pooled, washed (with 1X phosphate buffered saline, PBS), counted, and centrifuged. The cell pellets were rinsed twice with PBS before proceeding with RNA isolation. Alternatively, the cell pellets were stored in 5 volumes of RNA Later (Ambion \#7021) at -20oC for RNA isolation at a later and more convenient time without compromising RNA quality or yield.

RNA ISOLATION: The following protocol was modified from BD Sciences/Clontech's Atlas ${ }^{\mathrm{TM}}$ Pure Total RNA Labeling Kit (User Manual PT3231-1, published 24 April, 2001) for the RNA isolation of cultured cells and subsequent DNase treatment of isolated RNA in microcentrifuge tubes. The procedure was optimized for the RNA isolation of $40 \times 10^{6}$ human hepatoma HepG2 cells, which yields $\sim 100 \mu \mathrm{g}$ RNA. Reagents in the protocol can be scaled up or down depending on the number of cells.

\section{RNA Isolation Materials needed}

1X PBS buffer

Denaturing solution (kit)

Saturated phenol (Sigma \#P-4682)

Chloroform (Sigma \#C-2432)

Isopropanol (Sigma \#I-9516)

80 percent ethanol (Aldrich \#E702-3)

RNase-free water (kit)

26 gauge needle (sterile)
1.7-mL microcentrifuge tubes (RNase-DNase free)

Ice bath

Vortex

Tabletop centrifuge

50-mL conical tube (sterile)

$1000-\mu \mathrm{L}$ pipet and pipet tips (RNase-DNase free)

$100-\mu \mathrm{L}$ pipet and pipet tips (RNase-DNase free)

$10-\mathrm{mL}$ syringe (sterile) 


\section{RNA Isolation Procedure}

1. Transfer $40 \times 10^{6}$ cells to a sterile $50-\mathrm{mL}$ conical tube.

2. Centrifuge at $500 \mathrm{x}$ g for 5 minutes at $4{ }^{\circ} \mathrm{C}$; discard supernatant.

3. Rinse pellet with $\sim 25 \mathrm{~mL}$ of $1 \mathrm{X}$ PBS buffer (rinse cell pellet in RNA Later the same way).

4. Centrifuge at $500 \mathrm{x}$ g for 5 minutes at $4{ }^{\circ} \mathrm{C}$; discard supernatant. Repeat rinse.

5. Add $1.0 \mathrm{ml}$ denaturing solution, and IMMEDIATELY vortex to mix.

6. Pass contents through a syringe with a 26 gauge needle $\sim 10$ times to shear DNA or until the DNA strands are no longer lumpy. Transfer contents into a $1.7-\mathrm{mL}$ microcentrifuge tube.

7. Allow resuspended pellet to sit on ice for $5-10$ minutes.

8. Vortex, then centrifuge at $15,000 \mathrm{xg}$ for 5 minutes at $4^{\circ} \mathrm{C}$.

9. Transfer supernatant into two new microcentrifuge tubes.

10. Add $0.67 \mathrm{~mL}$ of saturated phenol to each tube and vortex for $\sim 1$ minute.

11. Incubate the tubes on ice for 5 minutes.

12. Add $0.2 \mathrm{~mL}$ of chloroform to each tube, shake and vortex for $1-2$ minutes.

13. Incubate the tubes on ice for 5 minutes.

14. Centrifuge at $15,000 \mathrm{x}$ g for 10 minutes at $4^{\circ} \mathrm{C}$.

15. Transfer top aqueous phase to a new tube, repeat steps $10-14$ another three times for a total of four Phenol-Chloroform extractions. Avoid pipetting into the interphase or organic phase.

16. Transfer top aqueous phase to a new tube and add $0.67 \mathrm{~mL}$ isopropanol slowly.

17. Mix well and let tubes sit on ice for 10 minutes.

18. Centrifuge at $15,000 \mathrm{x}$ g for 10 minutes at $4^{\circ} \mathrm{C}$.

19. Carefully remove and discard supernatant. Use care not to disturb the RNA pellet.

20. Add $0.5 \mathrm{~mL}$ of 80 percent ethanol.

21. Centrifuge at $15,000 \times \mathrm{g}$ for 5 minutes at $4^{\circ} \mathrm{C}$.

22. Carefully remove and discard supernatant. Use care not to disturb the RNA pellet.

23. Air dry pellet.

24. Resuspend RNA pellet in RNase-free water to about $2 \mu \mathrm{g} / \mu \mathrm{L}$ (about $20 \mu \mathrm{L} /$ tube) and combine RNA from the same treatment into a tube.

25. Determine RNA purity and yield [see details next page].

26. Perform phenol:chloroform cleanup if the RNA sample is still contaminated with proteins.

27. Continue with DNase treatment of RNA, or store RNA at $-80^{\circ} \mathrm{C}$ for treatment later.

DNase Treatment of RNA Materials needed

RNA sample

10X DNase buffer (kit)

DNase 1 (kit)

RNase-free water (kit)

10X termination mix (kit)

Chloroform (Sigma \#C-2432)

$2 \mathrm{M} \mathrm{NaOAc}$ (kit)
1.7-mL microcentrifuge tubes (Rnase-DNase free)

Air incubator $\left(37^{\circ} \mathrm{C}\right)$

Tabletop centrifuge

$10-\mu \mathrm{L}$ pipet and pipet tips

$100-\mu \mathrm{L}$ pipet and pipet tips

96 percent ethanol (Aldrich \#E702-3)

80 percent ethanol (Aldrich \#E702-3) 


\section{DNase Treatment of RNA Procedure}

1. This protocol assumes the DNase treatment of $\sim 100 \mu \mathrm{g}$ total RNA (at $2 \mu \mathrm{g} / \mu \mathrm{L}$ ) collected from 1 set of RNA extraction from $40 \times 10^{6}$ cells.

2. Follow the table below for the appropriate volumes of reagents needed. Depending on the amount of RNA to be treated, scale up or down accordingly.

\begin{tabular}{|c|c|c|c|c|c|}
\hline \multicolumn{6}{|c|}{$\begin{array}{l}\text { Table } 2 \\
\text { Reagents and Volumes Required for DNase Treatment of RNA }\end{array}$} \\
\hline Step \# & Reagent & $100 \mu \mathrm{g}$ RNA & $200 \mu \mathrm{g}$ RNA & $300 \mu \mathrm{g}$ RNA & $400 \mu \mathrm{g}$ RNA \\
\hline \multirow[t]{5}{*}{3} & $\mathrm{RNA}$ at $1 \mu \mathrm{g} / \mu \mathrm{L}(\mu \mathrm{L})$ & 100 & 200 & 300 & 400 \\
\hline & 10X DNase 1 buffer $(\mu \mathrm{L})$ & 20 & 40 & 60 & 80 \\
\hline & DNase 1 at $1 \mathrm{U} / \mu \mathrm{L}(\mu \mathrm{L})$ & 10 & 20 & 30 & 40 \\
\hline & Water $(\mu \mathrm{L})$ & 70 & 140 & 210 & 280 \\
\hline & Total $(\mu \mathrm{L})$ & 200 & 400 & 600 & 800 \\
\hline \multirow[t]{2}{*}{5} & 10X Termination Mix $(\mu \mathrm{L})$ & 20 & 40 & 60 & 80 \\
\hline & & Keep in 1 tube & Keep in 1 tube & Split into 2 tubes & Split into 2 tubes \\
\hline \multirow[t]{2}{*}{6} & Phenol $(\mu \mathrm{L})$ & 200 & 400 & 300 & 400 \\
\hline & Chloroform $(\mu \mathrm{L})$ & 120 & 240 & 180 & 240 \\
\hline 10 & Chloroform $(\mu \mathrm{L})$ & 220 & 440 & 330 & 440 \\
\hline \multirow[t]{2}{*}{13} & $2 \mathrm{M} \mathrm{NaOAc}(\mu \mathrm{L})$ & 20 & 40 & 30 & 40 \\
\hline & 96 percent Ethanol $(\mu \mathrm{L})$ & 500 & 1000 & 750 & 1000 \\
\hline 15 & 80 percent Ethanol $(\mu \mathrm{L})$ & 100 & 200 & 300 & 400 \\
\hline
\end{tabular}

3. In a $1.7-\mathrm{mL}$ microcentrifuge tube, mix:

$50 \mu \mathrm{L}$ total RNA $(100 \mu \mathrm{g})$

$20 \mu \mathrm{L} 10 \mathrm{X}$ DNase buffer

$10 \mu \mathrm{L}$ DNase $1(1 \mathrm{unit} / \mu \mathrm{L})$

$120 \mu \mathrm{L}$ RNase-free water

(Vortex, then centrifuge the tube for a few seconds to pull the contents to the bottom).

4. Incubate at $37^{\circ} \mathrm{C}$ for 1 hour.

5. Add $20 \mu \mathrm{L}$ of $10 \mathrm{X}$ Termination Mix and mix well (split contents into two tubes when treating $300 \mu \mathrm{g}$ or more).

6. Add $200 \mu \mathrm{L}$ of saturated phenol and $120 \mu \mathrm{L}$ chloroform, and vortex vigorously.

7. Centrifuge at $15,000 \mathrm{x} g$ for 10 minutes.

8. Transfer top aqueous layer to a new 1.7-mL microcentrifuge tube.

9. Repeat steps $6-8$ for another round of phenol:chloroform cleanup.

10. Add $220 \mu \mathrm{L}$ of chloroform and vortex well.

11. Centrifuge at $15,000 \mathrm{xg}$ for 10 minutes.

12. Transfer top aqueous layer into a $1.7-\mathrm{mL}$ microcentrifuge tube.

13. Add $20 \mu \mathrm{L}$ of $2 \mathrm{M} \mathrm{NaOAc}$ and $500 \mu \mathrm{L}$ of 96 percent ethanol, and vortex well.

14. Centrifuge at $15,000 \times \mathrm{g}$ for 20 minutes.

15. Carefully remove and discard supernatant. Overlay pellet with $100 \mu \mathrm{L}$ of 80 percent ethanol.

16. Centrifuge at $15,000 \mathrm{x}$ g for 10 minutes.

17. Carefully remove and discard supernatant. Air dry pellet for 10 minutes.

18. Dissolve the RNA pellet in $30 \mu \mathrm{L}$ of RNase-free water.

19. Pool RNA from the same treatment into a tube and mix well. 
20. Determine RNA purity and yield.

21. Adjust RNA concentration to $2 \mu \mathrm{g} / \mu \mathrm{L}$ with RNase-free water or with RNA storage solution for long-term storage.

22. Store RNA in $25 \mu \mathrm{L}(50 \mu \mathrm{g})$ aliquots at $-80^{\circ} \mathrm{C}$.

Determining RNA purity and yield:

Materials needed

$10 \mu \mathrm{L}$ pipette and tips

RNA storage solution (0.1 mM EDTA)

$1000 \mu \mathrm{L}$ pipette and tips

O.D. buffer (50 mM Tris, $0.1 \mathrm{mM}$ EDTA, pH 7.5)

1 -ml quartz cuvettes (2)

1. Transfer $4 \mu \mathrm{L}$ of RNA sample into a $1-\mathrm{mL}$ quartz cuvette.

2. Add $996 \mu \mathrm{L}$ of O.D. buffer.

3. Measure $\mathrm{A}_{260}$ and $\mathrm{A}_{280}$ using 1-mL O.D. buffer as a blank. Calculate yield:

Total $\mathrm{A}_{260}=\mathrm{A}_{260}$ of dilute sample $\mathrm{x} 250$ (dilution factor)

Concentration $(\mu \mathrm{g} / \mathrm{mL})=$ Total $\mathrm{A}_{260} \times 40 \mu \mathrm{g} / \mu \mathrm{L}$

Yield $(\mu \mathrm{g})=$ volume of RNA $(\mathrm{mL}) \times$ concentration $(\mu \mathrm{g} / \mathrm{mL})$

Purity $=\mathrm{A}_{260} / \mathrm{A}_{280}$ 


\section{APPENDIX B}

Listing of genes consistently responding at all doses for the given compound/mixture. Fold induction represents a gene's normalized treatment intensity of the treatment divided by that of the control. Both fold induction and p-values were calculated by the NLR statistical program of Kepler et al. (2002). ${ }^{1}$

\begin{tabular}{|c|c|c|c|c|c|c|c|}
\hline \multirow{2}{*}{$\begin{array}{l}\text { Gene } \\
\text { Location }\end{array}$} & \multirow[b]{2}{*}{ Gene ID } & \multicolumn{2}{|c|}{$\begin{array}{c}\text { Aroclor } 1254 \\
1 \mu \mathrm{g} / \mathrm{L} \text { (low) }\end{array}$} & \multicolumn{2}{|c|}{$\begin{array}{c}\text { Aroclor } 1254 \\
10 \mu \mathrm{g} / \mathrm{L} \text { (medium) }\end{array}$} & \multicolumn{2}{|c|}{$\begin{array}{c}\text { Aroclor } 1254 \\
100 \mu g / L \text { (high) }\end{array}$} \\
\hline & & Fold induction & $p$-value & Fold induction & $p$-value & Fold induction & $p$-value \\
\hline \multicolumn{8}{|c|}{ Up-regulated genes } \\
\hline B05f & $\begin{array}{l}\text { Catenin delta } 1 / \text { cadherin- } \\
\text { associated src substrate }\end{array}$ & 55 & 0.037 & 98 & $<0.001$ & 74 & 0.026 \\
\hline \multicolumn{8}{|c|}{ Down-regulated genes } \\
\hline G29 & Tubulin alpha 1 (TUBA 1) & 0.035 & $<0.001$ & 0.026 & 0.002 & 0.055 & 0.010 \\
\hline
\end{tabular}

\footnotetext{
${ }^{1}$ References cited in this appendix can be found in the "References" section of the main text.
} 
ERDC TN-DOER-R4

September 2004

\begin{tabular}{|c|c|c|c|c|c|c|c|}
\hline \multirow{2}{*}{$\begin{array}{l}\text { Gene } \\
\text { Location }\end{array}$} & \multirow[b]{2}{*}{ Gene ID } & \multicolumn{2}{|c|}{$\begin{array}{l}\text { PAH mixture } \\
17.4 \mu \mathrm{g} / \mathrm{L} \text { (low) }\end{array}$} & \multicolumn{2}{|c|}{$\begin{array}{c}\text { PAH mixture } \\
174 \mu \mathrm{g} / \mathrm{L} \text { (medium) }\end{array}$} & \multicolumn{2}{|c|}{$\begin{array}{l}\text { PAH mixture } \\
1740 \mu g / L \text { (high) }\end{array}$} \\
\hline & & Fold induction & p-value & Fold induction & p-value & Fold induction & p-value \\
\hline \multicolumn{8}{|c|}{ Up-regulated genes } \\
\hline $\mathrm{A} 06 \mathrm{~g}$ & $\begin{array}{l}\text { Homeobox protein A4 (HOXA4); } \\
\text { HOX1D; homeobox } 1 \text { cluster gene } \\
4 \text { homolog (HOX1.4) }\end{array}$ & 46 & 0.040 & 23 & 0.003 & 25 & 0.013 \\
\hline A11a & Fli1 proto-oncogene & 28 & 0.045 & 213 & $<0.001$ & 75 & 0.003 \\
\hline A13I & $\begin{array}{l}\text { Lupus LA ribonucleoprotein; } \\
\text { Sjogren syndrome type B antigen } \\
\text { (SSB) }\end{array}$ & 36 & 0.025 & 24 & $<0.001$ & 41 & 0.002 \\
\hline $\mathrm{c05a}$ & $\begin{array}{l}\text { Microsomal glutathione S- } \\
\text { transferase } 1 \text { (MGST1); GST12 }\end{array}$ & 24 & 0.033 & 62 & $<0.001$ & 101 & 0.009 \\
\hline $\mathrm{C06a}$ & $\begin{array}{l}\text { Erythrocyte urea transporter (UTE; } \\
\text { UT1); solute carrier family } 14 \\
\text { member } 1 \text { (SLC14A1); HUT11; } \\
\text { RACH1 }\end{array}$ & 32 & 0.030 & 124 & $<0.001$ & 65 & $<0.001$ \\
\hline G43 & Cytoplasmic beta-actin (ACTB) & 416 & $<0.001$ & 125 & 0.001 & 92 & $<0.001$ \\
\hline G45 & $\begin{array}{l}60 S \text { ribosomal protein L13A } \\
\text { (RPL13A); 23-kDa highly basic } \\
\text { protein }\end{array}$ & 233 & $<0.001$ & 260 & 0.003 & 116 & 0.023 \\
\hline \multicolumn{8}{|c|}{ Down-regulated genes } \\
\hline A07e & MAX protein & 0.015 & 0.044 & 0.008 & 0.019 & 0.003 & 0.002 \\
\hline B05n & $\begin{array}{l}\text { Intercellular adhesion molecule } 2 \\
\text { (ICAM2); CD102 antigen }\end{array}$ & 0.008 & $<0.001$ & 0.015 & 0.005 & 0.019 & 0.032 \\
\hline B10e & JunD proto-oncogene & 0.019 & 0.049 & 0.009 & 0.003 & 0.007 & 0.010 \\
\hline D02j & $\begin{array}{l}\text { 5,6-dihydroxyindole-2-carboxylic } \\
\text { acid oxidase (DHICA oxidase); } \\
\text { tyrosinase-related protein } 1 \text { (TRP- } \\
\text { 1); catalase B; glycoprotein-75 } \\
\text { (GP75) }\end{array}$ & 0.021 & 0.036 & 0.011 & 0.003 & 0.011 & 0.015 \\
\hline D10l & $\begin{array}{l}\text { Inhibitor of apoptosis protein } 3 \\
\text { (API3; IAP3); X-linked inhibitor of } \\
\text { apoptosis protein (X-linked IAP; } \\
\text { XIAP); IAP-like protein }\end{array}$ & 0.007 & $<0.001$ & 0.013 & 0.004 & 0.015 & 0.022 \\
\hline F13I & $\begin{array}{l}\text { Heart \& neural crest derivatives- } \\
\text { expressed protein } 1 \text { (HAND1) }\end{array}$ & 0.007 & 0.018 & 0.009 & 0.020 & 0.005 & 0.012 \\
\hline $\mathrm{F} 14 \mathrm{a}$ & KE05 protein & 0.006 & 0.014 & 0.010 & 0.023 & 0.003 & 0.002 \\
\hline
\end{tabular}


ERDC TN-DOER-R4

September 2004

\begin{tabular}{|c|c|c|c|c|c|c|c|}
\hline \multirow{2}{*}{$\begin{array}{l}\text { Gene } \\
\text { Location }\end{array}$} & \multirow{2}{*}{ Gene ID } & \multicolumn{2}{|c|}{$\begin{array}{l}2,3,7,8-T C D D \\
2.5 \mathrm{ng} / \mathrm{L} \text { (low) }\end{array}$} & \multicolumn{2}{|c|}{$\begin{array}{c}2,3,7,8-T C D D \\
7.5 \mathrm{ng} / \mathrm{L} \text { (medium) }\end{array}$} & \multicolumn{2}{|c|}{$\begin{array}{l}2,3,7,8-T C D D \\
100 \mathrm{ng} / \mathrm{L} \text { (high) }\end{array}$} \\
\hline & & Fold induction & p-value & Fold induction & p-value & Fold induction & $p$-value \\
\hline \multicolumn{8}{|c|}{ Up-regulated genes } \\
\hline A06k & $\begin{array}{l}\text { Caudal-type homeobox protein } 2 \\
\text { (CDX2); CDX3 }\end{array}$ & 40 & $<0.001$ & 38 & $<0.001$ & 65 & 0.009 \\
\hline B03n & $\begin{array}{l}\text { D-type cyclin-interacting protein } 1 \\
\text { (DIP1); GCIP; }\end{array}$ & 189 & 0.002 & 164 & 0.003 & 204 & $<0.001$ \\
\hline C01e & $\begin{array}{l}\text { Soluble epoxide hydrolase (SEH); } \\
\text { cytosolic epoxide hydrolase (CEH; } \\
\text { EPHX2; EPH2); epoxide } \\
\text { hydratase }\end{array}$ & 82 & 0.007 & 36 & 0.029 & 60 & $<0.001$ \\
\hline C06e & $\begin{array}{l}\text { Solute carrier family } 7 \text { member } 7 \\
\text { (SLC7A7); } y+L-\text {-type amino acid } \\
\text { transporter } 1 \text { (Y+LAT1) }\end{array}$ & 75 & 0.007 & 46 & 0.021 & 47 & 0.001 \\
\hline $\mathrm{C} 14 \mathrm{~m}$ & $\begin{array}{l}\text { ADP-forming succinate-CoA ligase } \\
\text { beta subunit (SUCLA2) }\end{array}$ & 93 & $<0.001$ & 113 & 0.000 & 287 & $<0.001$ \\
\hline $\mathrm{E} 02 \mathrm{~b}$ & $\begin{array}{l}\text { Connective tissue growth factor } \\
\text { (CTGF) }\end{array}$ & 67 & 0.013 & 67 & 0.021 & 130 & $<0.001$ \\
\hline E03h & $\begin{array}{l}\text { Small inducible cytokine subfamily } \\
\text { A member } 11 \text { (SCYA11); CC } \\
\text { chemokine eotaxin }\end{array}$ & 144 & 0.002 & 67 & 0.011 & 39 & 0.004 \\
\hline E04c & $\begin{array}{l}\text { Uromodulin; Tamm-Horsfall } \\
\text { urinary glycoprotein }\end{array}$ & 61 & 0.012 & 35 & 0.031 & 179 & $<0.001$ \\
\hline E06d & $\begin{array}{l}\text { Ephrin type-A receptor 2; epithelial } \\
\text { cell kinase (ECK); tyrosine-protein } \\
\text { kinase receptor ECK }\end{array}$ & 34 & 0.006 & 17 & 0.005 & 64 & 0.001 \\
\hline F01k & $\begin{array}{l}\text { Leukemia inhibitory factor receptor } \\
\text { (LIFR) }\end{array}$ & 90 & 0.004 & 38 & 0.025 & 65 & $<0.001$ \\
\hline F06f & $\begin{array}{l}\text { Sperm-associated antigen } 6 \\
\text { (SPAG6); REPROSA1 }\end{array}$ & 120 & $<0.001$ & 43 & 0.001 & 133 & $<0.001$ \\
\hline F06I & Beta crystallin B2 (CRYBB2); BP & 147 & 0.002 & 63 & 0.016 & 183 & $<0.001$ \\
\hline F09a & $\begin{array}{l}\text { 6-O-methylguanine-DNA } \\
\text { methyltransferase (MGMT); } \\
\text { methylated-DNA-protein-cysteine } \\
\text { methyltransferase }\end{array}$ & 88 & 0.007 & 68 & 0.006 & 314 & $<0.001$ \\
\hline F10c & DNA polymerase beta (POLB) & 174 & 0.002 & 65 & 0.003 & 185 & 0.001 \\
\hline $\mathrm{F} 10 \mathrm{e}$ & $\begin{array}{l}\text { DNA damage repair \& } \\
\text { recombination protein } 54 \text { homolog } \\
\text { (RAD54) }\end{array}$ & 55 & 0.002 & 24 & 0.001 & 55 & 0.011 \\
\hline F13c & $\begin{array}{l}\text { p53-induced gene } 8 \text { (PIG8); } \\
\text { etoposide-induced mRNA }\end{array}$ & 88 & 0.005 & 60 & 0.013 & 137 & $<0.001$ \\
\hline F13k & $\begin{array}{l}\text { Erythrocyte membrane protein } \\
\text { band } 7.2 \text { (EPB72); stomatin }\end{array}$ & 221 & $<0.001$ & 71 & 0.002 & 69 & 0.001 \\
\hline F14j & $\begin{array}{l}\text { Testis-enhanced gene transcript } \\
\text { (TEGT); BAX inhibitor } 1\end{array}$ & 39 & 0.021 & 44 & $<0.001$ & 101 & 0.003 \\
\hline
\end{tabular}

NOTE: The contents of this technical note are not to be used for advertising, publication, or promotional purposes. Citation of trade names does not constitute an official endorsement or approval of the use of such products. 